\title{
Wartość czasu pracy w podmiotach leczniczych. Dylematy, uregulowania, społeczno-moralne implikacje
}

\section{Wprowadzenie}

Praca, jej brak lub nadmiar, jej „kurczenie się” czy „rozszerzanie” stanowią - jak się wydaje - stałe i zawsze obecne problemy społeczne. Choć rzeczywistość tę cechuje pewna uniwersalność, to jednak ich lokalizacja wyraża się w różnorodnych kontekstach aktywności człowieka. Jednak - co podpowiada obserwacja życia społecznego - praca ma miejsce w specyficznej strukturze relacyjnej, najczęściej kojarzonej jako dychotomiczna, z tej racji, że dokonuje się w przestrzeni stosunków pomiędzy pracodawcami a pracobiorcami. Choć jedną i drugą stronę wiele różni, zwłaszcza co do struktury - choćby ze względu na specyfikę wzajemnych świadczeń - obie scala i ukierunkowuje jeden podstawowy cel, jakim jest dobrostan człowieka. Jednostka ludzka zmaga się na co dzień z wyzwaniami dotyczącymi jakości własnej i cudzej egzystencji. Kształtuje także swój etos, wpisujący się w szeroki ludzki kontekst, który to nauki społeczne określają jako człowieczeństwo¹.

\footnotetext{
* Ks. DR hab. PAwę Prürer, profesor AJP, Akademia im. Jakuba z Paradyża w Gorzowie Wielkopolskim, Wydział Ekonomiczny, Katedra Zarządzania Procesami Gospodarczymi, e-mail: paweljazz@o2.pl, ORCID: 0000-0003-3647-8068.

** Mgr Bernadeta Piszczygłowa - doktorantka Uniwersytetu Ekonomicznego w Poznaniu, e-mail: bernadeta.piszczyglowa@wp.pl, ORCID: 0000-0002-5865-5363.

1 Za cenne opracowanie w zakresie tego, co rozumiane jest jako człowieczeństwo, można uznać filozoficzno-socjologiczną analizę brytyjskiej badaczki Margaret Scotford Archer; zob. M.S. Archer, Człowieczeństwo. Problem sprawstwa, tłum. A. Dziuban, Kraków 2013.
} 
Działanie człowieka nie dokonuje się w próżni. Przestrzeń wypełniona wielością przedmiotów, a przede wszystkich relacjami i powiązaniami międzyludzkimi, staje się obszarem zarówno samorealizacji, jak i aktywności ukierunkowanej na innych. Abstrahując od zbyt filozoficznego kategoryzowania oraz interpretowania pewnych faktów, należałoby zaznaczyć jednak, że wszystko to dokonuje się nie tylko w określonej przestrzeni, lecz także w czasie, w jego ontologicznej i emergentnej strukturze. Czas nie tylko jest koniecznością, która określa strukturę bytu ludzkiego i świata, lecz także stanowi narzędzie - dodajmy, cenne narzędzie - dla realizacji potrzeb, rozwoju, wnoszenia do życia jednostkowego i społecznego określonych dóbr. Innymi słowy, czas jest wartością. Jest nią na tyle znacząco, że Franco Ferrarotti postrzega ludzki byt właśnie przez pryzmat czasu, który się wcielił, który inkarnował się w człowieka².

Dla podmiotów leczniczych, w których dokonuje się szeroko rozumiana aktywność usługowa na rzecz jednostek wykazujących się określonymi potrzebami, w tym głównie zdrowotnymi, czas pracy, sprawność wykonywanych usług, skuteczność i umiejętności koordynacji wielu działań, stanowią cenne narzędzie, z którego korzystają wszyscy, zarówno usługodawcy, jak i usługobiorcy. Czas sam w sobie jest wartością, a więc także czas pracy ma swoją cenę i wartość. Jest pewnym zasobem, czyli czymś, w co można inwestować. Jest też specyficznym środowiskiem zewnętrznym, do którego człowiek się adaptuje poprzez swoje działanie. W końcu jest horyzontem intencjonalności działania, co oznacza, że odniesienie do niego stwarza możliwość konstruowania aktywności i tożsamości ${ }^{3}$.

W niniejszym artykule nie tylko jednak w ten sposób chcielibyśmy eksplorować zagadnienie czasu pracy w podmiotach leczniczych. Nasza idea oscyluje wokół kwestii czasu jako wartości, którą rozpatruje się z w pewnym sensie jako dobro rzadkie, a więc traktuje się je z szacunkiem. Proponujemy teoretyczny pryzmat, w którym - w pewnym sensie - można rozpoznawać czas pracy jako dobro rzadkie i jako wartość cenną samą w sobie. Stąd chcemy wskazać między innymi na kwestie równowagi w dystrybucji czasu, na równoważenie wartości czasu z uwzględnieniem jego maksymalizacji oraz dążenia do jak największej efektywności w gospodarowaniu nim, a minimalizowaniem jego „użycia” ze względu na jego wartość dla jednostek znajdujących się poza kontekstem zawodowym, instytucjonalnym.

Czas na pracę i czas na wypoczynek, maksymalizacja jego „użycia” oraz maksymalizacja jego „swobodnego" biegu to ostatecznie próba znajdowania pewnej równowagi w dobrym funkcjonowaniu podmiotów leczniczych, w kształtowaniu dobrostanu pacjentów i personelu medycznego oraz w pozytywnym przekładaniu

2 F. Ferrarotti, Scienza e coscienza. Verità personali e pratiche pubbliche, Bologna 2014, s. 53.

3 T. Szlendak, Co się dzieje z czasem wolnym? Od codziennego znoju i odpoczynku do codzienności, w której czas eksplodował, w: Barwy codzienności. Analiza socjologiczna, red. M. Bogunia-Borowska, Warszawa 2009, s. 202. 
się wskazanych determinantów na losy jednostek i grup społecznych. W tym celu przeanalizowano dostępną $\mathrm{w}$ tym zakresie literaturę - $\mathrm{w}$ większości specjalistyczną z zakresu zarządzania podmiotami leczniczymi - oraz zastosowano pewien horyzont interpretacyjny charakterystyczny dla analiz z zakresu nauk społecznych. Bliska nam i inspirująca jest teza sformułowana przez Domenico De Masi, który przekonuje, że konieczna jest następująca postawa umysłu i działania: „lasciare il tempo necessario per metabilizzarne gli effetti”4 [pozwolić, by w stosownym czasie dokonała się metabolizacja rezultatów]. Potrzeba czasu na pracę i potrzeba tegoż na wypoczynek są nie tylko trampoliną dla skutecznych efektów działań, ale i dla głębokiej refleksji nad wartością czasu i tego wszystkiego, czego człowiek dokonuje dzięki jego dynamice ciągłości.

\section{Wartość czasu pracy pracowników w podmiotach leczniczych - wartość mierzona liczbami i przedmiot kalkulacji?}

Podmioty lecznicze są specyficznymi instytucjami. Ich charakter kształtowany jest w oparciu o ukierunkowanie przede wszystkim na świadczenie usług. Wokół podstawowego celu, jakim jest dobro pacjentów, realizowane są inne rodzaje aktywności (zarządzanie, administrowanie, inwestowanie, restrukturyzowanie, rewitalizowanie, humanizowanie itd.). Wszystko to dokonuje się w określonym czasie, którego nie należy postrzegać jedynie w pryzmacie maksymalizowania jego efektywności. Logika darmowości, daru i wrażliwości, wykraczająca poza czysty mechanizm kalkulacji, dystrybucji i wymiany, jest cennym narzędziem komplementarności i suplementacji strukturalno-funkcjonalnej podmiotów społecznych $^{5}$. Nie tylko czysta i wyrachowana wymiana, lecz i sprawiedliwa rozdzielczość oraz inklinacja prospołeczna mogą i powinny charakteryzować świat rynków, systemów i instytucji ${ }^{6}$. Czas pracy podmiotów może być rozpatrywany w pryzmacie jego oszczędzania, wydłużania, inwestowania, konstruowania, obdarowywania. Przyjrzyjmy się najpierw ogólnemu znaczeniu czasu pracy, rozpatrywanego w odniesieniu do pracowników podmiotów leczniczych.

Czas pracy pracowników zatrudnionych w podmiotach leczniczych określono w ustawie o działalności leczniczej ${ }^{7}$. W podmiotach leczniczych może

4 D. De Masi, Mappa mundi. Modelli di vita per una società senza orientamento, Milnao 2015, s. 824.

5 Congregazione per Dottrina della Fede, Dicastero per il Servizio dello Sviluppo Integrale, Oeconomicae et pecuniariae questiones. Considerazioni per un'discernimento etico circa alcuni aspetti dell'attuale sistema economico-finanziaria, Città del Vaticano 2018, s. 8.

6 Benedykt XVI, Encyklika "Caritas in veritate». O integralnym rozwoju ludzkim w miłości i prawdzie, Kraków 2009, s. 42.

7 Ustawa $z$ dnia 15 kwietnia 2011 roku o działalności leczniczej, „Dziennik Ustaw” z 2018 roku, poz. 160 . 
obowiązywać maksymalnie trzymiesięczny okres rozliczeniowy. Ustawodawca wskazał, że w przyjętym okresie rozliczeniowym czas pracy pracowników zatrudnionych w podmiotach leczniczych nie może przekraczać 7 godzin i 35 minut na dobę, oraz przeciętnie 37 godzin i 55 minut na tydzień, w średnio pięciodniowym tygodniu pracy w przyjętym okresie rozliczeniowym, z zastrzeżeniem równoważnego systemu czasu pracy oraz z wyłączeniem pracowników niewidomych, których czas pracy nie może przekraczać odpowiednio 5 i 25 godzin. Jedynie pracownicy techniczni, obsługi i gospodarczy mają czas pracy określony w kodeksie pracy, tzn. 8 godzin na dobę i przeciętnie 40 godzin na tydzień. Jak więc widać, stosowana jest niewielka, a jednak istotna dywersyfikacja dotycząca długości czasu pracy, w zależności od statusu pracowniczego osób zatrudnionych w podmiotach leczniczych. Można więc założyć, że wartość czasu pracy wynika z rodzaju aktywności, a przede wszystkim z jej ukierunkowania na określony przedmiot działania.

W podmiotach leczniczych obowiązują systemy i rozkłady czasu pracy: podstawowy, zmianowy z określeniem liczby godzin (zazwyczaj 8 lub 12 godzin na dobę) oraz system czasu pracy równoważny (do 12 godzin na dobę). Takie rozwiązania stosuje się przede wszystkim do pielęgniarek i położnych oraz średniego personelu medycznego, za wyjątkiem pracownic w ciąży oraz pracowników opiekujących się dzieckiem do lat czterech.

Pracownikom, którzy wykonują zawód medyczny i są zatrudnieni w podmiocie leczniczym wykonującym działalność leczniczą w rodzaju stacjonarnych i całodobowych świadczeń zdrowotnych w systemie pracy zmianowej, przysługują dodatki. Za każdą godzinę pracy wykonywanej w porze nocnej przysługuje dodatek w wysokości co najmniej 65\% stawki godzinowej wynagrodzenia zasadniczego, zaś za każdą godzinę pracy wykonywanej w porze dziennej w niedziele i święta oraz $\mathrm{w}$ dni wolne od pracy wynikające z przeciętnie pięciodniowego tygodnia pracy dodatek w wysokości co najmniej $45 \%$ stawki godzinowej wynagrodzenia zasadniczego. Takie wysokości dodatków wyznacza ustawa o działalności leczniczej, natomiast pracodawca może przyznać dodatki wyższe, może te je przyznać również pracownikom niebędącym pracownikami medycznym i niewymienionym w ustawie o działalności leczniczej.

Powyższe informacje dotyczące regulacji czasu pracy wyraźnie wskazują, że ma on swoją wartość w zależności od cyklu dobowego, w którym zakłada się, że praca wykonywana w określonych, nietypowych godzinach (np. nocnych) jest inaczej wartościowana niż w przypadku standardowego jej przebiegu (np. w ciągu dnia). Można więc na tej podstawie stwierdzić, że w podmiotach leczniczych czas pracy w jego wymiarze subiektywnym, to znaczy w doświadczeniu pracującej jednostki, „rozszczepia się” od jego obiektywnego biegu, to znaczy

\footnotetext{
8 S. Molęda, Prawo dla lekarzy i zakładów opieki zdrowotnej, Warszawa 2008, s. 280.
} 
od jego ciągłości, która jest nieuchronna i niezależna od kontekstu doświadczanego przez konkretną jednostkę. W tym wymiarze istnieje synergia uznaniowa pomiędzy jednostkowym a społecznym i instytucjonalnym wartościowaniem czasu pracy. Instytucje (w tym przypadku pracodawca podmiotu leczniczego) wartościuje pracę w jej wymiarze czasowym, uwzględniając jej ukontekstowienie. Dotyczy to nie tylko uznania większej trudności w wykonywaniu pracy w nocnym wymiarze, ale także wyłączania lub choćby minimalizowania w okresie świątecznym, niedzielnym. Niezależnie jednak od takich i podobnych działań regulacyjnych w tym zakresie, czas wolny jest wciąż kategorią będącą pochodną czasu pracy, jego długości, miejsca i sposobów jego zagospodarowania?.

Cyrkularność biegu czasu jako takiego oraz jego przebiegu w wymiarze wykonywania pracy w podmiocie leczniczym nie są w tym znaczeniu zbieżne i rozszczepiają się w różnych własnych trajektoriach. Liczba godzin pracy jest tu więc mierzona i kalkulowana na podstawie specyfiki prowadzonej aktywności zawodowej, a tym samym ilość czasu jest wartością, która określa, mierzy i odzwierciedla poziom obiektywnych trudności związanych z pracą. Poziom wartości czasu pracy będzie więc w tym przypadku determinowany specyfiką kontekstu „przyrodniczo-astronomicznego", w którym pojawiają się cyklicznie pory dnia i nocy. Będzie również sankcjonowany i instytucjonalizowany społecznie, kulturowo i instytucjonalnie, poprzez ustalenie dni wolnych od pracy, przypisywanie go do wymiaru świątecznego. Tym samym czas pracy staje się wartością zapośredniczoną przez strukturę społeczną, co czyni go trwałym i silnym. W przypadku braku takiego zapośredniczenia można by słusznie twierdzić za Amitai Etzionim, że byłby on wartością słabą, kruchą, a w dalszej perspektywie niemożliwą do utrzymania ${ }^{10}$.

Trudno zaprzeczyć, by wspomniana logika była niewłaściwa, tym bardziej jeśli uwzględni się podstawowe prawa i potrzeby jednostek, ich godność osobową, szacunek dla zachowania ich integralności i wspieranie ich dobrostanu psychofizycznego. Jest ona charakterystyczna dla cywilizacji, która przechodzi kolejne stadia pozytywnego rozwoju, tak w sensie ilościowych, jak i jakościowych jego determinantów. Można powołać się tu na klasyka nauk społecznych, który słusznie upatruje w rozwoju i postępie cywilizacji zarówno zmniejszania się niebezpieczeństw ze strony natury, jak i hamulca niewłaściwych działań ludzkich ${ }^{11}$.

9 L. Milian, Socjologia czasu wolnego. Wiedza o czynnościach swobodnie wybieranych, Gdańsk 2010, s. 35 .

10 A. Etzioni, Aktywne społeczeństwo. Teoria procesów społecznych, tłum. S. Burdziej, Kraków 2012, s. 34 .

${ }^{11}$ F. Znaniecki, Ludzie teraźniejszości a cywilizacja przyszłości, Warszawa 2001, s. 60. 


\section{Praca na dyżurze medycznym - przyrost wartości wykonywanej pracy?}

Pełnienie obowiązków, które mają charakter społeczny lub zawodowy, dokonuje się w określonym przedziale czasu. Taka aktywność jest dokonywana w oparciu o określone warunki. Ma się tu do czynienia z kategorią czasu pracy, określanej jako dyżur. Ten rodzaj wykonywania określonych działań nie jest w przypadku każdego rodzaju spełnianych obowiązków zawodowych jakimś odwzorowywaniem pewnej stałej matrycy. Dyżur może być w określonym miejscu i czasie nacechowany intensywnością działań, w innym przypadku jest tylko pewną dyspozycyjnością podmiotu oferującego pewne usługi. Jednak, co stanowi istotny element, kwestia czasu pełnionego dyżuru stanowi jakby najistotniejszy jego element. Niezależnie od jego faktycznego „wypełnienia” czas dyżurowania jest determinantą określająca warunki porozumienia pomiędzy pracodawcą a pracownikiem. W przypadku beneficjentów korzystających $\mathrm{z}$ dyspozycyjności dyżurującego istotnym elementem jest skuteczne korzystanie $\mathrm{z}$ określonego świadczenia, które jest udostępniane w tym wyznaczonym przedziale czasu. W tym kontekście można sformułować następujące pytania: Czy w przypadku podmiotów leczniczych ma się do czynienia z jakimś specyficznym rodzajem pracy wykonywanej podczas dyżury medycznego? I czy jest on może wartością, którą pacjent ceni z jakichś szczególnych względów? Fakt, że wielorako rozumiane usługi medyczne zarówno w literaturze przedmiotu, jak i w praktyce planowania działań w systemie ochrony zdrowia rozpatrywane są w kategorii tzw. konsumpcji świadczeń, sprawia, że można je traktować jako pożądane i istotne wartości ${ }^{12}$.

Lekarze oraz personel posiadający wyższe wykształcenie medyczne mogą zostać zobowiązani do pełnienia dyżurów medycznych. Dyżurem medycznym jest wykonywanie poza normalnymi godzinami pracy czynności zawodowych przez wyżej wskazane osoby w podmiocie leczniczym oferującym stacjonarne i całodobowe świadczenia zdrowotne. Ustawy i rozporządzenia w tym zakresie informują o zobowiązaniach pracownika podmiotu leczniczego do pełnienia dyżuru medycznego, co ma charakter polecenia pracodawcy i nie wymaga szczególnej formy, więc może być indywidualnym poleceniem adresowanym wyłącznie do konkretnego pracownika ze wskazaniem godzin jego dyżuru, ujętym $\mathrm{w}$ miesięcznym planie czy harmonogramie dyżurów ${ }^{13}$. Czas pracy dyżuru medycznego wliczany jest do ogólnego czasu pracy. Lekarze oraz personel posiadający wyższe wykształcenie medyczne, zobowiązani do pełnienia dyżurów medycznych, mogą wyrazić zgodę na pracę powyżej 48 go-

12 Ł. Raciborski, Stan zdrowia, w: Współczesne społeczeństwo polskie, red. A. Giza, M. Sikorska, Warszawa 2012, s. 119.

13 Ustawa o działalności leczniczej z dnia 15 kwietnia 2011 r., „Dziennik Ustaw” z 2011 roku, poz. 654. 
dzin w tygodniu w przyjętym okresie rozliczeniowym. Zgoda powinna zostać wyrażona na piśmie. W tym celu podpisują tzw. klauzule opt-out. W przypadku braku zgody pracownika na pracę powyżej 48 godzin w tygodniu pracodawca nie może podejmować działań dyskryminujących wobec tych pracowników. $\mathrm{Ma}$ się tu więc do czynienia $\mathrm{z}$ pewnym wychyleniem normatywnym, które uwzględnia godność osoby w jej wyborach opartych o sumienie i przekonania. Trafnie twierdzi Janusz Mariański, że dostrzega się coraz częściej skłonność do poszanowania pewnej „wsobnej” wartości, co jest także jakimś newralgicznym punktem współczesnych społeczeństw i kultur ${ }^{14}$.

Praca w ramach dyżuru medycznego wynagradzana jest podobnie jak praca w godzinach nadliczbowych. Zasad tych nie stosuje się do lekarzy stażystów, których zasady wynagradzania określają odrębne przepisy. Istotnym jest to, że w przypadku dyżuru medycznego nie stosuje się przepisów Kodeksu pracy dotyczących limitu godzin nadliczbowych. Dyżur medyczny stanowi odrębną od pracy w godzinach nadliczbowych kategorię pracy ponadwymiarowej, wynagradzanej podobnie jak praca w godzinach nadliczbowych. Wskazuje to na dopuszczalność dopełnienia niewypracowanych normalnych godzin pracy lekarza godzinami dyżuru medycznego, ponieważ dyżurem medycznym jest wykonywanie przez lekarzy czynności poza normalnymi godzinami pracy w podmiocie leczniczym wykonującym stacjonarne i całodobowe świadczenia zdrowotne. $Z$ tego powodu normalne godziny pracy nie wypełniają umówionego wymiaru czasu pracy, dlatego zobowiązanie lekarza do pełnienia dyżuru medycznego jest dopełnieniem (uzupełnieniem) normalnych godzin pracy ${ }^{15}$.

Analiza aktów prawnych oraz praktyka wykonywania czynności medycznych w podmiotach leczniczych pozwala na stwierdzenie, że praca w ramach dyżurów medycznych musi być szczegółowo i rzetelnie ewidencjonowana. Pracodawca prowadzi ewidencję czasu pracy pracownika do celów prawidłowego ustalenia jego wynagrodzenia i innych świadczeń związanych z pracą. Pracodawca udostępnia tę ewidencję pracownikowi na jego żądanie. W stosunku do pracowników objętych systemem zadaniowego czasu pracy, pracowników zarządzających w imieniu pracodawcy zakładem pracy oraz pracowników otrzymujących ryczałt za pracę w godzinach nadliczbowych lub za pracę w porze nocnej nie ewidencjonuje się godzin pracy. Pracodawca jest zobowiązany prowadzić i przechowywać ewidencję czasu pracy pracowników oraz udostępniać ją organom właściwym do sprawowania nadzoru i kontroli nad przestrzeganiem prawa pracy, które mogą, z powodów związanych $\mathrm{z}$ bezpieczeństwem lub zdrowiem pracowników, a także w celu zapewnienia właściwego poziomu udzielania świadczeń zdrowotnych,

14 J. Mariański, Godność ludzka w kontekście społecznym. Szkice ze społecznego nauczania Kościoła katolickiego, Lublin 2017, s. 17.

15 Z. Kubot, Harmonogramy pracy lekarzy (regulacje prawne, przykłady, spory), Wrocław 2014, s. 13. 
zakazać albo ograniczyć możliwość wydłużenia maksymalnego tygodniowego wymiaru czasu pracy. Warto podkreślić w tym kontekście dość osobliwy fakt, że nadzór i kontrola, jak na to wskazują analizy teoretyczne i empiryczne, a także klasyczna myśl socjologiczna, są domeną kształtowania się społeczeństwa dyscyplinarnego, którego tło jest jeszcze bardziej rozległe, ponieważ odsyła do procesów historycznych, ekonomicznych, prawno-politycznych i naukowych ${ }^{16}$.

Problem, który jest tu omawiany, nie dotyczy jedynie kontekstu dyżurów lekarzy oraz personelu posiadającego wyższe wykształcenie medyczne. Pracodawca może zobowiązać również pracowników innych grup zawodowych do pełnienia dyżuru, tj. pozostawania poza normalnymi godzinami pracy w gotowości do wykonywania pracy wynikającej z umowy o pracę w zakładzie pracy lub w innym miejscu wyznaczonym przez pracodawcę. Czasu dyżuru nie wlicza się do czasu pracy, jeżeli podczas dyżuru pracownik nie wykonywał pracy, jednak czas pełnienia dyżuru nie może naruszać prawa pracownika do odpoczynku. Należy pamiętać, że przeciążenie obowiązkami może generować przewlekłe znużenie, wyczerpanie i ciężką chorobę ${ }^{17}$. Za czas dyżuru, z wyjątkiem tego pełnionego w domu, pracownikowi przysługuje czas wolny od pracy w wymiarze odpowiadającym długości dyżuru, a w razie braku możliwości udzielenia czasu wolnego wynagrodzenie wynikające $\mathrm{z}$ jego osobistego zaszeregowania, określonego stawką godzinową lub miesięczną. W przypadku, kiedy taki składnik wynagrodzenia nie został wyodrębniony przy określaniu warunków wynagradzania, przysługuje mu on w kwocie $60 \%$. Przepisów tych nie stosuje się do pracowników zarządzających w imieniu pracodawcy zakładem pracy.

Rzeczywisty stan funkcjonowania podmiotów leczniczych wskazuje na istotny problem wewnętrzny tych instytucji. Obecnie w podmiotach leczniczych istnieje kwestia tzw. „zejściówek” po dyżurach. Na skutek zmian i wytycznych resortu zdrowia wprowadzono lekarzom, personelowi posiadającemu wyższe wykształcenie medyczne oraz dyżurującemu w takim systemie, obowiązkowe "zejście” po dyżurze medycznym, określając tygodniową normę czasu pracy do 48 godzin. Z praktyki i doświadczeń wielu pracowników wynika, że wbrew takim ustaleniom szpitale potrącają lekarzom zejście pod dyżurze. $Z$ etycznego punktu widzenia jest to zjawisko godzące w aksjonoramtywny system regulujący relację między instytucją a jednostką. Zakłócona zostaje priorytetowość podmiotu względem systemu i instytucji. Lekarz, a w konsekwencji także pacjent narażeni są na perturbacje wynikające $\mathrm{z}$ wdrażania logiki ilościowości i pragmatyzmu, z pomniejszaniem troski o integralność i dobrostan psychofizyczny konkretnych osób. Takie działania i mechanizmy są z puntu widzenia

16 M. Foucault, Nadzorować i karać. Narodziny więzienia, tłum. T. Komendant, Warszawa 2009, s. 212.

17 J. Pięta, Pedagogika czasu wolnego, Warszawa 2008, s. 32. 
etycznego niemoralne i niegodziwe. Nawet jeśli ocena etyczna w takim lub podobnym przypadku bywa postrzegana jako zagrażająca - ponieważ potępiająca działania manipulacyjne i degradujące osoby ${ }^{18}$ - warto ją uwzględniać także w naukowym i społecznym dyskursie, szczególnie wtedy, kiedy podejmuje się dyskusję dotyczącą zasad i wartości.

\section{Czas pracy i czas wypoczynku lekarzy - wartość narzędzia ze względu na dobrostan pacjentów i lekarzy}

Zasadniczy rys funkcjonalno-strukturalny podmiotów leczniczych opiera się na pracy personelu lekarskiego. Zdrowie pacjentów, czyli podstawowych beneficjentów usług i aktywności podejmowanej przez lekarzy, jest głównym wyznacznikiem funkcjonowania podmiotów leczniczych. Warto jednak zauważyć, że istotnym korelatem w realizacji tego celu jest także komfort pracy lekarzy, ich dobrostan psychofizyczny, niepozostający bez wpływu na całościowy aspekt realizacji usług zdrowotnych. We współczesnej literaturze dotyczącej kwestii zdrowia, w tym tzw. społecznej jego natury, zwraca się uwagę na prozdrowotne style życia, oraz z tym związane zjawiska komercjalizacji, utowarowienia i konsumpcji zdrowia ${ }^{19}$. Nierzadko rozpatruje się także powiązanie jakości życia osób $\mathrm{z}$ tym, co stanowi o zdrowiu społeczeństwa jako takiego ${ }^{20}$. Ponadto, jak nietrudno się przekonać, same odniesienia społeczne, relacje międzyludzkie, to, co jest nazywane kapitałem społecznym, istotnie determinują poczucie dobrostanu, czy po prostu wzmacniają potencjał zdrowotny jednostek ${ }^{21}$. Brakuje jednak - jak się wydaje - szerszej dyskusji nad zagadnieniem promocji i wspierania aspektów prozdrowotnych personelu medycznego z myślą nie tylko o skuteczności ich działania w wykonywaniu funkcji zawodowych, lecz także wspierania dobrostanu psychofizycznego lekarzy. Jest to kwestia tym bardziej istotna, że wszystkie opisane zjawiska dokonują się w specyficznej atmosferze, która nie pozostaje bez wpływu na złożoną rzeczywistość medyczną i zdrowotną. Zauważa się we współczesnej kulturze i zbiorowej mentalności - co jest artykułowane głównie

18 Franciszek, Adhortacja apostolska «Evangelii gaudium». O Głoszeniu Ewangelii w dzisiejszym świecie, Kraków 2013, s. 34.

19 Z. Słońska, Zdrowie, w: Encyklopedia Socjologii, red. W. Kwaśniewicz i inni, t. 4, S-Ż, Warszawa 2002, s. 357.

20 F. Vaia, Introduzione, w: F. Vaia, B. Morsello, C. Cilona, M.A. Citarella, Giovani e salute. Un'indagine in tema di prevenzione, stili do vita e rapporto con il servizio sanitario nei giovani dell'area metropolitana di Roma, Roma 2019, s. 7.

${ }_{21}$ D. Halpern, Zdrowie i dobre samopoczucie, tłum. M. Lubaś, w: Socjologia codzienności, red. P. Sztompka, M. Bogunia-Borowska, Kraków 2008, s. 711. 
przez socjologów medycyny - „społeczne zakwestionowanie dominacji i autorytetu medycyny"22.

Istotny problem $\mathrm{w}$ tym powyższym kontekście stanowi czas pracy lekarzy. Sposób jego rozliczania sprawia, że $\mathrm{w}$ wielu regionach kraju pojawiają się wyraźne deficyty w tym zakresie. $Z$ uwagi na zdrowie pracowników polski ustawodawca wprowadził do krajowego porządku prawnego nakazy udzielania im minimalnych okresów dobowego i tygodniowego odpoczynku, więc nie mógł ustanowić pozytywnych przepisów sankcjonujących naruszenie tych nakazów, dlatego z wykładni wynika, że niezapewnienie pracownikowi gwarantowanych norm odpoczynku w przyjętym okresie rozliczeniowym jest zagrożone obowiązkiem wypłaty adekwatnego wynagrodzenia lub odszkodowania. Regulacja czasu pracy lekarzy różni się od regulacji czasu pracy zawartej w przepisach Kodeksu pracy, gdyż przeciętny tygodniowy wymiar czasu pracy w przyjętym okresie rozliczeniowym jest krótszy od powszechnie obowiązujących 40 godzin i wynosi 37 godzin i 55 minut. W części z nich występują okresy związane z koniecznością zapewnienia pacjentom całodobowej opieki, tzw. dyżur medyczny oraz pozostawania poza zakładem pracy w gotowości do udzielania świadczeń zdrowotnych ${ }^{23}$. Dodatkowym warunkiem jest to, by równoważny okres odpoczynku był udzielany bezpośrednio po ostatnim okresie wykonywania w danej dobie pracy naruszającej odpoczynek dobowy, w wymiarze, który dopełni okres odpoczynku po zakończeniu pracy do 11 godzin. Oznacza to, że pracownik będzie mógł podjąć pracę dopiero po upływie kolejnych 11 godzin od zakończenia pracy w poprzedniej dobie. Zatem niezapewnienie pracownikowi pełniącemu dyżury medyczne nieprzerwanego dobowego i tygodniowego odpoczynku gwarantowanego w art. 3 i 5 dyrektywy Rady ${ }^{24}$ oraz art. 3 i 5 dyrektywy Parlamentu Europejskiego ${ }^{25}$ implementowanych do prawa polskiego jako art. 132 i 133 Kodeksu pracy, nie powinno pozostawać bez jakichkolwiek sankcji dla pracodawcy i rekompensaty dla pracownika. Dyrektywa ta reguluje zagadnienia maksymalnego czasu pracy i minimalnego czasu odpoczynku, kwestie wynagradzania pozostają poza jej regulacją.

W należytym funkcjonowaniu podmiotów leczniczych, w zgodzie z przepisami i z poszanowaniem pracy personelu medycznego ustala się grafiki dyżurów

${ }^{22}$ M. Skrzypek, Ewolucja relacji lekarz-pacjent w kontekście upodmiotowienia laików w opiece zdrowotnej, w: Zaufanie społeczne. Teoria - idee - praktyka, red. J. Szymczyk, Warszawa 2016, s. 351.

23 M.B. Rycak, Czas petnienia dyżuru medycznego wlicza się do czasu pracy, „Dziennik Gazeta Prawna" 2009, nr 132, s. 1.

24 Dyrektywa Rady 93/104/WE z dnia 23 listopada 1993 r. dotyczaca niektórych aspektów organizacji czasu pracy, https://eur-lex.europa.eu/legal-content/pl/TXT/?uri=CELEX\%3A31993L0104 [dostęp: 23.09.2019].

${ }_{25}$ Dyrektywa Parlamentu Europejskiego i Rady nr 2003/88/WE z dnia 04 listopada 2003 r. dotycząca niektórych aspektów czasu pracy, https://eur-lex.europa.eu/legal-content/PL/ TXT/?uri=CELEX:32003L0088 [dostęp: 23.09.2019]. 
przy zachowaniu prawa lekarzy do odpoczynku. Ustawodawca nie limituje liczby dyżurów medycznych przez wskazanie ich dopuszczalnej liczby, jednak zgadza się w tym zakresie ze wskazaną wyżej dyrektywą Rady, zgodnie z którą dyżur medyczny wlicza się do czasu pracy i nie stanowi pracy w godzinach nadliczbowych w rozumieniu postanowień Kodeksu pracy. Pracownicy zatrudnieni $\mathrm{w}$ niepełnym wymiarze czasu pracy mogą w tygodniu dyżurować tyle samo co pełnoetatowi pracownicy. Wyżej opisane zasady dotyczą również lekarzy rezydentów, którzy pełnią dyżury samodzielne. Natomiast lekarze rezydenci, którzy pełnią dyżury towarzyszące oraz lekarze stażyści pełnią dyżury w ilości średnio 10 godzin i 5 minut tygodniowo zgodnie z rozporządzeniem w sprawie specjalizacji lekarzy i lekarzy dentystów ${ }^{26}$ oraz rozporządzeniem Ministra Zdrowia o stażu podyplomowym lekarza i lekarza dentysty ${ }^{27}$.

Istnieje kolejna kwestia, którą warto tutaj wyartykułować. Zamiast dyżuru medycznego podmiot leczniczy może zlecić lekarzom lub innemu personelowi posiadającemu wyższe lub średnie wykształcenie medyczne pozostawanie w gotowości poza zakładem do udzielania świadczeń. Również w tym przypadku należy udzielić czasu wolnego po zakończeniu świadczenia pracy, jeżeli pracownik został wezwany i wykonywał obowiązki pracownicze. Za każdą godzinę pozostawania w gotowości do udzielania świadczeń zdrowotnych przysługuje pracownikowi wynagrodzenie w wysokości 50\% stawki godzinowej wynagrodzenia zasadniczego, którą oblicza się, dzieląc kwotę miesięcznego wynagrodzenia zasadniczego wynikającą z osobistego zaszeregowania pracownika przez liczbę godzin pracy przypadających do przepracowania w danym miesiącu. Natomiast w przypadku wezwania do podmiotu leczniczego zastosowanie mają przepisy dotyczące dyżuru medycznego.

Przytoczone wyżej kwestie dotyczące czasu pracy lekarzy oraz rozporządzeń prawnych $\mathrm{z}$ tym związanych, pozwalają dostrzec $\mathrm{w}$ skrupulatnie regulowanej materii przejaw rzeczywistej troski i ochrony przez zbytnią skłonnością struktur i instytucji do zapośredniczania i zawłaszczania sfery zawodowej i egzystencjalnej konkretnych jednostek. Wartości są regułami wolności, jak twierdzi wybitny socjolog Piotr Sztompka. Człowiekowi towarzyszy osobliwe dążenie: aspirowanie z jednej strony do autonomii i niezależności, a z drugiej do podmiotowości i sprawstwa ${ }^{28}$. W realizacji tych dążeń struktury i instytucje nie powinny stanowić przeszkody, lecz stawać się elementem wsparcia i ochrony. Czas pracy lekarzy jest ostatecznie istotną determinantą $\mathrm{w}$ realizacji poprawności kompleksowego dobra, które wyłoni się zarówno z jakości samej pracy lekarzy,

26 Rozporządzenie z dnia 02 stycznia 2013 roku, „Dziennik Ustaw” z 2013 roku, poz. 26.

27 Rozporządzenie z dnia 26 września 2012 roku, „Dziennik Ustaw” z 2012 roku, poz. 95.

28 P. Sztompka, Socjologiczne pojęcie wartości. Wykład z okazji nadania doktoratu honoris causa przez Akademię Pedagogiki Specjalnej im. Marii Grzegorzewskiej w Warszawie, w: Doktor honoris causa Akademii Pedagogiki Specjalnej im. Marii Grzegorzewskiej Piotr Sztompka, Warszawa 2017, s. 45. 
z przyjętej przez pacjentów jakości usług, jak i z poprawności funkcjonowania podmiotów leczniczych jako instytucji i struktur.

Dodajmy, że specyfika pracy lekarzy (podobnie jak i wielu innych profesji) oparta jest na osobliwym sprzężeniu pomiędzy pewną cyklicznością i powtarzalnością wykonywanych usług zdrowotnych (Anthony Giddens przekonuje, że właśnie w powtarzalności jest czas $^{29}$ ), a wciąż nowymi i wyjątkowymi wyzwaniami, które ulokowane są głównie w stałej zmienności pacjentów, oczekujących na realizację osobistej potrzeby poprzez doprowadzenia ich do równowagi psychofizycznej. Choć stwierdzenie, że lekarze, podobnie jak wszyscy inni członkowie społeczeństwa prowadzą także życie prywatne i rodzinne, wydaje się dość banalne, nie jest już kwestią banalną rozziew i brak refleksyjności między światem pracy a życie rodzinnym, co zaobserwował i opisał Pierpaolo Donati w swojej książce Sociologia della riflessività. Come si entra nel dopo-moderno ${ }^{30}$.

\section{Zakończenie}

Czas jest wartością, którą można rozumieć wielorako. W konkretnym czasie dokonują się i rozstrzygają się różnorodne problemy, również te związane z rzeczywistością dotyczącą funkcjonowania podmiotów leczniczych. Można wskazać na kwestie bardziej ogólne, a dotyczące obecnego czasu, jak na przykład fakt, że żyjemy dłużej, lecz szybciej zapadamy na choroby ${ }^{31}$. Można także sondować szczegółowo detale związane z regulacjami dotyczącymi czasu pracy w podmiotach medycznych. We wszystkich tych obszarach czas odgrywa istotną rolę i jest głównym wyznacznikiem funkcjonowania oraz działania zarówno struktur, jak i sprawczych podmiotów jednostkowych. Jednostki odkrywające w konkretnym czasie swoje poczucie sprawstwa, doceniając rolę czynników społecznych, strukturalnych, zewnętrznych względem nich, pozostają istotami autonomicznymi i podmiotowymi w swoich działaniach ${ }^{32}$. Procesy te są dynamiczne, konsekutywne i twórcze.

W niniejszym artykule wskazywaliśmy zarówno bezpośrednio, jak i pośrednio na różne wymiary i znaczenia czasu. W kontekście pracy, w tym pracy związanej z funkcjonowaniem instytucji leczniczych, wyłania się on jako wartość obiektyw-

29 A. Giddens, Życie w społeczeństwie posttradycyjnym, w: U. Beck, A. Giddens, S. Lash, Modernizacja refleksyjna. Polityka, tradycja i estetyka w porządku społecznym nowoczesności, tłum. J. Konieczny, Warszawa 2009, s. 87.

30 P. Donati, Sociologia della riflessività. Come si entra nel dopo-moderno, Bologna 2011, s. 311.

31 P. Carnaglia-Ferraris, La salute non ha prezzo, w: Il pregiudizio universale. Un catalogo d'autore di pregiudizi e luoghi comuni, red. G. Antonelli i inni, Bari-Roma 2016, s. 321.

32 J. Mariański, Godność ludzka jako wartość społeczno-moralna: mit czy rzeczywistość? Studium interdyscyplinarne, Toruń 2016, s. 455. 
na, czyli pewien stan mający znaczenie dla wielu podmiotów zaangażowanych $\mathrm{w}$ ich funkcjonowanie. Jest on rzeczywistością doświadczaną, zewnętrzną i wewnętrzną, zarówno wplecioną w działalność praktyczną jednostek, jak i istniejącą w wyobraźni, pamięci, intuicji oraz w rozumieniu i ocenie aksjonormatywnej. Jest więc w pewien sposób tożsamy z działaniem, które dana jednostka kieruje na przedmiot. Jest umiejscowiony w człowieku, ma charakter podmiotowy. Jest także zewnętrznym „przedmiotem”, obiektem potrzeby, kształtującym postawy, wpływającym na pragnienia, dynamizującym lub hamującym aktywność jednostki. Ma szczególny wpływ na psychiczny i afektywno-poznawczy wymiar jednostki. Ostatecznie czas pracy to determinanta, która w pewnym sensie staje się wszechogarniającą rzeczywistością bytową, gdyż osadzoną w pozapodmiotowej rzeczywistości człowieka, lecz wnikającym w głąb jego podmiotowości ${ }^{33}$.

Funkcjonowanie podmiotu leczniczego jest ostatecznie funkcjonowaniem pewnej ludzkiej zbiorowości, instytucji, która oprócz specyficznej struktury organizacyjno-funkcjonalnej stanowi przecież ludzką wspólnotę. A jak każda inna taka struktura relacyjna wypełniona podmiotami opiera się na wartościach. Te z kolei wydają się być obiektywnie niezmienne i niezależne od społecznych kontekstów ${ }^{34}$. Jest wątpliwą sprawą, czy wspólnota może te wartości w związku z tym negocjować, choć przecież - co, mamy nadzieję, choćby w części wykazała nasza analiza - są one przedmiotem namysłu, regulacji, problematyzacji. Czas, na którym osadza się aktywność zawodowa, usługowa i społeczna jednostek związanych z działaniem podmiotu leczniczego, stanowi wartość nie do przecenienia. Nieuchronność upływu czasu oraz zarządzanie nim w funkcjonowaniu podmiotu leczniczego nie jest ani problemem stricte filozoficznym, ani także wyłącznie ekonomicznym.

\section{Bibliografia}

Archer M.S., Człowieczeństwo. Problem sprawstwa, tłum. A. Dziuban, Kraków 2013.

Benedykt XVI, Encyklika «Caritas in veritate». O integralnym rozwoju ludzkim w miłości i prawdzie, Kraków 2009.

Bogunia-Borowska M., Życie w dobrym społeczeństwie. Wartości jako fundament dobrego społeczeństwa, w: Fundamenty dobrego społeczeństwa. Wartości, red. M. Bogunia-Borowska, Kraków 2015, s. 13-45.

Carnaglia-Ferraris P., La salute non ha prezzo, w: II pregiudizio universale. Un catalogo d'autore di pregiudizi e luoghi comuni, red. G. Antonelli i inni, Bari-Roma 2016, s. 318-321.

Congregazione per Dottrina della Fede. Dicastero per il Servizio dello Sviluppo Integrale, Oeconomicae et pecuniariae questiones. Considerazioni per un'discernimento etico circa alcuni aspetti dell'attuale sistema economico-finanziaria, Città del Vaticano 2018.

${ }_{33}$ M. Ziółkowski, Wartości, w: Encyklopedia Socjologii, t. 4, S-Ż, s. 289-291.

34 M. Bogunia-Borowska, Życie w dobrym społeczeństwie. Wartości jako fundament dobrego społeczeństwa, w: Fundamenty dobrego społeczeństwa. Wartości, red. M. Bogunia-Borowska, Kraków 2015, s. 22. 
De Masi D., Mappa mundi. Modelli di vita per una società senza orientamento, Milno 2015.

Donati P., Sociologia della riflessività. Come si entra nel dopo-moderno, Bologna 2011.

Dyrektywa Parlamentu Europejskiego i Rady nr 2003/88/WE z dnia 04 listopada 2003 r. dotyczaca niektórych aspektów czasu pracy, https://eur-lex.europa.eu/legal-content/PL/ TXT/?uri=CELEX:32003L0088 [dostęp: 23.09.2019].

Dyrektywa Rady 93/104/WE z dnia 23 listopada 1993 r. dotyczqca niektórych aspektów organizacji czasu pracy, https://eur-lex.europa.eu/legal-content/pl/TXT/?uri=CELEX\%3A31993L0104 [dostęp: 23.09.2019].

Etzioni A., Aktywne społeczeństwo. Teoria procesów społecznych, tłum. S. Burdziej, Kraków 2012. Ferrarotti F., Scienza e coscienza. Verità personali e pratiche pubbliche, Bologna 2014.

Foucault M., Nadzorować i karać. Narodziny więzienia, tłum. T. Komendant, Warszawa 2009.

Franciszek, Adhortacja apostolska «Evangelii gaudium». O Głoszeniu Ewangelii w dzisiejszym świecie, Kraków 2013.

Giddens A., Życie w społeczeństwie posttradycyjnym, w: U. Beck, A. Giddens, S. Lash, Modernizacja refleksyjna. Polityka, tradycja i estetyka w porządku społecznym nowoczesności, tłum. J. Konieczny, Warszawa 2009, s. 79-144.

Halpern D., Zdrowie i dobre samopoczucie, tłum. M. Lubaś, w: Socjologia codzienności, red. P. Sztompka, M. Bogunia-Borowska, Kraków 2008, s. 678-720.

Kubot Z., Harmonogramy pracy lekarzy (regulacje prawne, przykłady, spory), Wrocław 2014.

Mariański J., Godność ludzka jako wartość społeczno-moralna: mit czy rzeczywistość? Studium interdyscyplinarne, Toruń 2016.

Mariański J., Godność ludzka w kontekście społecznym. Szkice ze społecznego nauczania Kościoła katolickiego, Lublin 2017.

Milian L., Socjologia czasu wolnego. Wiedza o czynnościach swobodnie wybieranych, Gdańsk 2010. Molęda S., Prawo dla lekarzy i zakładów opieki zdrowotnej, Warszawa 2008.

Pięta J., Pedagogika czasu wolnego, Wydanie II, Warszawa 2008.

Raciborski Ł., Stan zdrowia, w: Współczesne społeczeństwo polskie, red. A. Giza, M. Sikorska, Warszawa 2012, s. 103-138.

Rozporzqdzenie z dnia 02 stycznia 2013 roku, „Dziennik Ustaw” z 2013 roku, poz. 26.

Rozporządzenie z dnia 26 września 2012 roku, „Dziennik Ustaw” z 2012 roku, poz. 95.

Rycak M.B., Czas pełnienia dyżuru medycznego wlicza się do czasu pracy, "Dziennik Gazeta Prawna” 2009, nr 132, s. 1-2.

Skrzypek M., Ewolucja relacji lekarz-pacjent w kontekście upodmiotowienia laików w opiece zdrowotnej, w: Zaufanie społeczne. Teoria - idee - praktyka, red. J. Szymczyk, Warszawa 2016, s. 349-369.

Słońska Z., Zdrowie, w: Encyklopedia Socjologii, red. W. Kwaśniewicz i inni, t. 4, S-Ż, Warszawa 2002, s. 354-359.

Szlendak T., Co się dzieje z czasem wolnym? Od codziennego znoju i odpoczynku do codzienności, w której czas eksplodował, w: Barwy codzienności. Analiza socjologiczna, red. M. Bogunia-Borowska, Warszawa 2009, s. 201-214.

Sztompka P., Socjologiczne pojęcie wartości. Wykład z okazji nadania doktoratu honoris causa przez Akademię Pedagogiki Specjalnej im. Marii Grzegorzewskiej w Warszawie, w: Doktor honoris causa Akademii Pedagogiki Specjalnej im. Marii Grzegorzewskiej Piotr Sztompka, Warszawa 2017. Ustawa o działalności leczniczej z dnia 15 kwietnia 2011 r., "Dziennik Ustaw” z 2011 roku, poz. 654. Ustawa z dnia 15 kwietnia 2011 roku o działalności leczniczej, „Dziennik Ustaw” z 2018 roku poz. 160. Vaia F., Introduzione, w: F. Vaia, B. Morsello, C. Cilona, M.A. Citarella, Giovani e salute. Un'indagine in tema di prevenzione, stili do vita e rapporto con il servizio sanitario nei giovani dell'area metropolitana di Roma, Roma 2019, s. 7-9.

Ziółkowski M., Wartości, w: Encyklopedia Socjologii, t. 4, S-Ż, red. W. Kwaśniewicz i inni, Warszawa 2002, s. 289-297.

Znaniecki F., Ludzie teraźniejszości a cywilizacja przyszłości, Warszawa 2001. 


\title{
Wartość czasu pracy w podmiotach leczniczych. Dylematy, uregulowania, społeczno-moralne implikacje
}

\begin{abstract}
Streszczenie
Czas jest zarówno wartością samą w sobie, jak i wartością użyteczną. Podmioty lecznicze korzystają $\mathrm{z}$ tej wartości w wieloraki sposób. Czas pracy personelu medycznego, pełnione dyżury oraz czas wypoczynku regulowane są formalnymi przepisami prawa. Wartość czasu pracy uzależniona jest od rodzaju jej wykonywania, podmiotu który ją wykonuje oraz od uwarunkowań oraz kontekstu kulturowo-społecznego. Istotnym elementem określającym wartość czasu pracy jest ostatecznie odniesienie do człowieka jako podmiotu i priorytetu wszelkich działań społecznych. Dotyczy to zarówno szeroko rozumianego dobra lekarzy, jak i pacjentów. Jest to perspektywa etyczna i aksjologiczna, której nie powinno się pomijać w funkcjonowaniu i zarządzaniu podmiotami leczniczymi.
\end{abstract}

Słowa kluczowe: czas, czas pracy, podmiot leczniczy, lekarz, dyżur medyczny, wartości

\section{Value of working time in medical entities. Dilemmas, regulations, social and moral implications}

\section{Abstract}

Time is a value in itself and a useful one. Medical entities use this value in many ways. The medical staff's working time spent carrying out medical duty and rest periods are regulated by formal laws. The value of working time depends on the type of work, the entity that carries it out, as well as the cultural and social context. An important element determining the value of working time is ultimately the reference to the human being as the subject and priority of all social activities. This applies to the broadly understood good of doctors and patients. This is an ethical and axiological perspective that should not be overlooked in the functioning and management of medicinal entities.

Key words: time, working time, medicinal entities, doctor, medical duty, values 